\title{
Homogeneity within Heterogeneity: Insights from the Culture of West Kameng of Arunachal Pradesh
}

Prasanta Kumar Nayak ${ }^{\dagger}$

\section{Abstract}

As the world moves faster towards a homogenised culture, the logic of keeping heterogeneous properties of culture seems asynchronous. The liberalisation, privatisation, and globalisation (LPG) model of growth and development of states throw challenges to the indigenous cultures and traditions for a state like India where diverse traditional moorings, cultural systems, religious practices and ethnic variations stand core to its integrity. In the rat-race for development, indigenous cultures and traditions of a state are enmeshed within 'accept the global go and lose insularity' or 'decline it to stay homogeneous'. In a homogeneous societal culture, the underlying values and beliefs are squarely believed, shared and practised compared to many different values and beliefs professed by diverse population groups in case of a heterogeneous one.

Arunachal Pradesh with twenty-six major tribes and numerous sub-tribes at its credit stands incredible for its ethnicity, tribal indigenous identities, and cultural homogeneity. As is the number, so is the variation with indigeneity and nuances of culture practised by the tribes. The cultural diversity of the people differs from tribe to tribe even if they reside within the same geographical area. The district West Kameng is abode to six different tribes-Akas, Buguns, Mijis, Monpas, Sajalongs and Sherdukpens living in close proximity with each other. However, their traditional culture with regards to their religious practices, dress, customs, rituals, languages, dialects, fairs and festivals is starkly heterogeneous. Most remarkable is the criterion that heterogeneity hardly aberrates homogeneity within themselves. The focus of the present study is to highlight such a homogeneity-heterogeneity aspect of the culture of West Kameng.

Keywords: Homogeneity; Heterogeneity; Pluriculturalism; West Kameng; Arunachal Pradesh; India

\footnotetext{
${ }^{\dagger}$ Associate Professor, Department of History, Rajiv Gandhi University, Rono Hills, Doimukh, Arunachal Pradesh,791 112, Email: prachipkn@rediffmail.com

(C) 2020 Nayak. This is an Open Access article distributed under the terms of the Creative Commons Attribution License (http://creativecommons.org/licenses/by/2.0), which permits unrestricted use, distribution, and reproduction in any medium, provided the original work is properly cited.
} 


\section{Introduction}

Culture is the way of life, especially the general customs and beliefs, of a particular group of people at a particular time (Cambridge English Dictionary, 2020). It is the one which reflects the social behaviour and norms of the human society and the knowledge, beliefs, arts, laws, customs, capabilities, and habits of the individuals living in it (Tylor, 1871). The present world is heading towards a homogenised culture breaking the barriers of differences across nations and challenging the heterogenised properties of the individual culture practised. Debates surface as to how a harmonious concatenation is to become a reality within the hegemonic global process of 'one world' theory. The globalisation, liberalisation and privatisation (LPG) model of development advocated by the developed nations naturally has its effect over India. The withdrawal of controls and regulations by the government on establishment and running of industries, opening of the door of industrial activities to the private sector and allowing a free flow of goods and services, labour technology, investments in a country stood as its basic objectives. It throws challenges to the indigenous cultures and traditions across the world, particularly for a state like India where diverse traditional moorings, cultural systems, religious practices and ethnic variations stand core to its integrity. Scholars contemplate it to be a panacea for the developing ones (Grugel et al., 2008, pp. 502503). The spate of the impact of the notion of 'one world' has churned the human mind. Issues and challenges around the notion from their genesis to denouement have asked state planners and strategists to review the lurch of development and retrospect its acoustics. Changes are felt rationalised, policies balanced out, fallacies screened, economy recast and utility homogenised cutting across barriers and fissures. Indian state mechanism gets too underway.

In the rat-race for development, indigenous cultures and traditions of a state are enmeshed within 'accept the global go and lose insularity' or 'decline it to stay homogeneous' - the motion of 'one world' results in the cultural mesh and dilution of the ethnic identities. Ethnicity, tribal indigenous entities and cultural homogeneity are marginalised under the concept of a 'global village' encouraging a 'mainstream presencing' and 'global ethnoconvergence'. The term 'global village is coined by the Canadian thinker Marshall McLuhan in the 1960s, based on his concept on the understanding of people moving towards involving personal interactions worldwide and the consequences, as they ensue and operate simultaneously with their causes (Hendricks, 2018). It is a phenomenon of the entire world which allows individuals to get interconnected by the processes of modernisation and opportunity for the expression of global citizenship via shared political interests (O'Byrne and Hensby, 2011, pp. 10-32).

Arunachal Pradesh, a distant northeastern state too stands for its beauty, not for nature's bliss but for the incredible ethnicity, tribal indigenous identities, cultural homogeneity and for 'interesting philological puzzle' as the ethnologists and anthropologists put it (Barthakur, 2006, p. 8). The state is home to twenty-six major tribes and numerous subtribes. As is the number, so is the variation with indigeneity and nuances of culture practised by the tribes. The local elements of culture have been seriously challenged under this process. The tribes of Arunachal consolidate on the premise of ethnic difference. The state is expected to bear the threat of anonymity and ethno-convergence significantly under the ambit of one world order.

Societal cultures, with a dominant set of values and beliefs, of course, are to vary. In a homogeneous societal culture, the underlying values and beliefs are believed, shared and practised giving rise to a dominant set of cultural beliefs to coherently exist. In contrast, with a heterogeneous one, many different values and beliefs are allowed to be professed by diverse groups (Enz, 1986, pp. 173-189). This leads to a kind of situation where the concept of a 
multicultural society becomes more prominent to prevail. This is where Arunachal Pradesh quite justifiably fits in. The cultural diversity of the people differs from tribe to tribe even if they reside within the same geographical area. The district West Kameng is abode to six different tribes-Akas, Buguns, Mijis, Monpas, Sajalongs and Sherdukpens living near each other. Nevertheless, their traditional culture with regards to their religious practices, dresses, customs, rituals, languages, dialects, fairs and festivals is starkly heterogeneous (Singh, 1995, pp. 135-288). Most remarkable is the criterion that heterogeneity hardly aberrates homogeneity within themselves. They co-exist, share and care. They feast, celebrate and exchange within them too. The focus of the present study is to highlight such homogeneityheterogeneity aspect concerning the culture prevalent in the district West Kameng. The study is developed on the basis of the researcher's personal association with the district for two decades as a college teacher and subsequently updated knowledge accrued while going through research publications related to tribes of the district.

The present study is going to base upon a review of the literature, followed by a theoretical exposition on homogeneity and heterogeneity. The degree of homogeneity-heterogeneity issues in the context of the tribes of the district of West Kameng of Arunachal Pradesh will also be examined before reaching out to the closure of the discussion.

\section{Review of Literature}

Culture and traditions practised in society stand out to be unique compared to its other counterparts. So also is the case with the Arunachal society. A traditionally prosperous society like that of it has witnessed the impact of outside forces but has been successful in retaining its insularity. The district of West Kameng is no exception to it. A good number of works go to highlight the different aspects of the traditions and culture of Arunachal Pradesh (Bose, 1997; Chaudhuri and Chaudhuri, 2016; Joshi, 2005; Mibang and Behera, 2007; Nath 2000; 2005; 2012; 2013; 2014; Nimachow, 2011;
Pathak and Gogoi, 2008; Singh and Riddi, 2017), but hardly examine the aspect the author is focusing on. Significantly, we find very less number of works so far have come up in respect of the tribes of the district West Kameng.

M. L. Bose's History of Arunachal Pradesh (1997) discusses the history, land, people and culture of the state. It also highlights about the British Policy and Administration, and Constitutional and Administrative Growth of Arunachal Pradesh, but deals very short about the 'Origins of Religion and Culture' of the tribes. However, D. S. Grewal, in his book Tribes of Arunachal Pradesh: Identity, Culture and Languages (1997) covers a detailed account of identification, grouping, classification and detailed description of tribal languages, phonetics and grammar of all tribes of Arunachal Pradesh.

In 2005, H. G. Joshi portrayed the history, culture, tribal ethos, social dynamics, administration, rituals and festivals, besides the advent of modern administration, development efforts, politics and modernisation while Nath (2000; 2005;2012; 2013; 2014) brings out a prismatic picture of the Adis, Monpas, Mijisand examines their origin, settlement, administrative system, and cultural aspects. The author's preparation of the chapter on religious aspects of the tribes is a revealing picture depicted with data drawn from the religious and cultural history of Tibet and other neighbouring countries but misses out the link to connect and compare their culture with other neighbouring tribes of the district on homogeneityheterogeneity line. For instance, in his 2014 book titled Cultural History of the Sherdukpens of Arunachal Pradesh, Nath holds its relevance on several aspects of Sherdukpen society accounting for their origin and migration, their marriage, family and sexual life, administrative system, life cycle birth, career, diseases, dreams, death, and religion and religious festivals. However, Nath (2014) fails to compare and contrast with other tribes.

In another significant move both Mibang and Behera (2007), in their edited volume Tribal Studies: Emerging Frontiers of Knowledge provide a definitive account of the dynamics of 
tribal studies with four thematic sectionsCulture and Identity, Expanding Frontiers in Tribal Studies, Development Perspectives and Social Process. Though it sheds welcome light on cultural pluralism and cultural hegemony but goes scanty nomenclating cultural practices of Arunachal Pradesh. However, Pathak and Gogoi (2008) highlight different tribe-based festivals observed in Arunachal, their rich cultural heritage, traditions and beliefs associated with them and their impact beyond the state. The book also includes some of the festivals of the tribes of the West Kameng like Losar of the Monpas and Sherdukpens, Nechido of the Akas, Dhoromjih and Khan of the Mijis, and KshyatSowai of the Khowas (Buguns) and links them to their respective culture practiced.

Similarly, in another scholarly monograph, Nimachow (2011) mapped about the Akas; their family type, marriage system, traditional village council, literary rate, infrastructure, agriculture, demography, forest resources, culture, changes taking place and transition of the Aka society in three different periods that is, postindependence, statehood period and the year 2000 onwards. A good reading of it can educate anyone on the Aka culture and its contribution to homogeneity in the district. In another authoritative work, Chaudhuri and Chaudhuri (2016) link the culture of the diversified bead practice of the different tribes with their folklore and beliefs, their utility and values, and their emerging realities in the society. It is an essential asset to be referred to while doing research on the culture of Arunachal Pradesh.

Seemingly, the edited volume titled Pre-Colonial History and Traditions of Arunachal Pradesh (2017) Singh and Riddi goes to focus on various issues related to society, culture, traditions, economy and political history of the region in the pre-colonial period. It too accommodates essays from Prof. A. K. Thakur on 'Cultural Development in Buddhism of Arunachal Pradesh: Probing Through Arts', Dr. Chhomu on 'A Study of the Economic Activities of the Monpa', Dr. N. T. Jose on 'Bon Culture of the Sherdukpen of West Kameng', Dr. Dusu Sambyo on 'Faith and Ritual Practices of the Aka: In
Changing Times', and Aditee Kumari on 'Traditional Political Institutions of the Monpas'. They all go to reflect the society, economy, polity and culture of the tribes of West Kameng. The book is relevant for the study of cultural aspects in the district. This study aims to unravel insights about homogeneity within heterogeneity by examining the culture of West Kameng, Arunachal Pradesh. The following section is an attempt to outline homogeneity versus heterogeneity.

\section{Homogeneity vs Heterogeneity}

The constitution of 'one' is said to be homogeneous when all constitutive elements making up that 'one' are strictly identical to each other. These elements are coherently placed, mutually calibrated and critically judged to get assembled under one real parameter. It goes heterogeneous when this condition is found absent. Here, the identity of the elements taken for consideration could be seen partially or in total. The constitution of homogeneity or heterogeneity is an attribute of a given critical component or set of critical components. It may cover a single component or all components (Gy, 1992, pp. 48-55). Contextual to it, a society with diversity in culture and tradition maintained and adhered to with unison, its identity is said perfectly calibrated, total and homogeneous, but is limited and heterogeneous when the component-elements making the culture diversified are not strictly uniform (Gy, 1992, pp. 48-55).To see a culture in a society diversified, one has to ensure that the society moves on a continuum from homogeneity to heterogeneity. A multicultural society (Enz, 1986, p. 173) comes to reality when an established set of cultural beliefs goes to exist and sustain; and when homogeneous societal culture allows its core values and beliefs held by diverse population groups to be shared and made allencompassing.

The logic of homogenisation was perhaps propounded, as Anil Bhatti (2009) writes, most concisely by Carl Schmitt whose study of constitutional law considers homogeneity as the basis for the relationship between the rulers and ruled. Despite a set of varied race, colour, and 
the religion practiced within a society, homogenisation goes to establish substantial equality as the basic precondition for democracy, which was found influencing the formulation of such ideology of the fascist German state (Bhatti, 2009, p. 43). A homogeneous societal culture is one in which the shared values and practices are similar, and little variation exists in beliefs; the culture has one dominant way to think and act (Enz, 1986, p. 173-189). Not that there exists no difference in such kind of societies. Diversity exists in all societies, but the factor which largely determines the characteristic of diversity is the degree of variation practiced and shared within the society. The less if seen and mentored out with harmony in consensus remains within the ambit of homogeneity; and the more if practiced and found non-accommodative to uniformity, goes to suggest a feature of heterogeneity. Adaptability in a homogeneous cultural set up is in many respects more effortless than in heterogeneous ones because of the people's acceptance of the society's dictation.

When numerous population groups in society practise their specific and distinct values and understandings, we see a heterogeneous societal culture grow with shared meanings of the values and beliefs (Enz, 1986, p. 173-189). These shared meanings may stand familiar to some groups but might vary for others. Such nature of a society certifies multiple cultures to coexist and workforce diversity to influence an individual's way of functioning. In contrast, different cultures tend to reflect the societal variety and distinct cultures to prevail. The Canadian psychologist Albert Bandura's Social Cognitive Theory (SCT) developed in 1986 seems quite relevant here for a reference. It was an extension of his Social Learning Theory (SLT) coined earlier in the 1960s. The SCT postulates that learning occurs in a social context with a dynamic and reciprocal interaction of the person, environment, and behaviour. It goes to state that when people observe a model performing a behaviour and its consequences, they remember the sequence of events and use this information to guide subsequent behaviours (Bandura, 1986 \& Bandura, 2008: pp.
94-124). Hence, it talks of a unique way to guide individuals to acquire, maintain and perform their behaviour according to the social environment. Their past experiences, the sequence of events, influences, reinforcements and expectations go together to shape their specific behaviour (Behaviorial Change Models, 2020).

The society can be monocultural or multicultural by characteristics allowing its cultures to be practiced either in the line of homogeneity or heterogeneity. In heterogeneous one, cultural diversity is bound to be there, and it is expected of. However, in a homogeneous societal culture, maintaining cultural diversity is felt stressful, and a much tighter bond exists between traditional and practised culture. There is most likely a possibility to occur that unexpected diversified forces are hard-pressed and mellowed down to conform to the dominant unified values and beliefs. Here the nature of differences zeroes down before the commonality of practices of a homogeneous culture Hence, making a cross-cultural comparison and assessment for society is like examining its features of homogeneity or heterogeneity.

In a heterogeneous society, the kind of culture practised is more likely to predict and explain its functioning and behaviour because it gets directly guided by the behaviour of the different sets of people. However, in a homogeneous society, the same trend goes to reflect a culture by unison and here the similarity between cultures, whether traditional or practiced is strongly felt. Examining societal culture may prove useful for explaining people's life. Nevertheless, once world history is viewed as unquestionably "shared" or "entangled", cultures could be seen as fluid and not bounded (Subrahmanyam, 1997, pp. 735-762). Borders go porous, and issues of solidarity get established across cultural spaces. As a sequel, cultural translatability, permeability and mutation despite being thwarted by associated problems become normal. Instead of bounded multicultural conditioning, more permeable communicatively open pluricultural conditions 
come in, and they characterise society Bhatti, 2009 , p. 37). Such pluricultural but communicatively permeable trends we experience across the tribes of West Kameng living very close to each other, which is being discussed in the following section

\section{Insights from West Kameng}

Arunachal Pradesh is known for its ethnic, linguistic, cultural, religious and physiographical diversities (Singh, 1995, pp. 1-54). Even within a particular district, such diversities are seen. The nuance of cultural and traditional diversities in the state is a fact incredible without personal experience. Even if globalisation has made its inroad deeper into the dynamism of the culture, traditionality is still in vogue. The dynamism in them is incredibly outstanding. And more the dynamism, more are the societies prone to cultural fusion. More the fusion more is the chance of acculturation [the process of assimilation of one culture into another (Cole, 2019)]. In the absence of commonalities, there can be no assimilation, and without assimilation, there can be no acculturation. It then becomes an issue of subordination of lesser by the more potent force. The lesser is inexorably pulled towards a commonality, stripped off its own ethno-identity.

India is a country where contemporary society is composed of elements that preserve the indelible marks of almost every historical stage. We can recognise here the issue of historical simultaneity. German philosopher Ernest Bloch calls it 'simultaneity of the non-simultaneous' or the 'synchronicity of the non-synchronous' as a characteristic of the complexity of the society (Bloch, 1977, pp. 22-38). Relatively homogeneous societies are developing into more complex social formations. On the other hand, existing complex societies are being subjected to tensions that may threaten their plurilingual and pluricultural composition. The languages spoken in the state belong to the Tibeto-Burman and Indo-Aryan families (Singh, 1995, p. 23). While each tribe follows its own exclusive traditions and customs, we find three cultural groups based on their socio-politicoreligious affinities; the first group is of the
Monpas and Sherdupens of Tawang and West Kameng districts following the Lamaistic tradition of Mahayana Buddhism; the second group comprises of the Adis, Apatanis, Tagins, Nyishis and Mishmis believing in the worshipping of the sun and moon gods, and the third group is of the Noctes, Tangsas, Singphos, Khamptis and Wanchos of the eastern part of the state believing in Vaisnavism, Buddhism and Naga culture (Gardner, 2019, pp.22-29). Modernisation and globalising processes are leading to long-term societal transformations. A modernisation is an act or process of developing or unfolding. It indicates advancement through progressive changes in the fabric of the society (Abid, 2004, p. 590) and Arunachal Pradesh is no way behind to come under the spell of modernisation. It has impacted on the people's traditional society; their belief system, culture, religion, education, dress, cuisine, housing pattern, and aesthetics etc. Traditionally, pluricultural countries like India which seemed to have muddled through to an uneasy systemic balance exemplified by the slogan of "unity in diversity" are now increasingly being subjected to fundamentalist pressures that may logically lead to more and more rigid forms of homogeneous organisation of socio-cultural and political units. However, practically, in Arunachal Pradesh, this theoretical framework remains far from being experienced despite its manifestation of the plurilingual and pluricultural composition of its people. Hence, we find a strong bonding among tribes. It is indeed a homogeneous bonhomie within heterogeneity.

The traditional culture of the tribes generally denotes their religion, dress, customs, rituals, languages, dialects, fairs, festivals; housestructure, priesthood, ethnomedicine and human-nature relationship practised within a society. Each tribal community is unique with its own traditional culture, customs, practices, language and folklore (Nadimpally, 2017). The cultural diversity of the people differs from tribe to tribe even if they reside within the same geographical area. The district West Kameng is the abode to six different tribes-Akas, Buguns, Mijis, Monpas, Sajolang and and Sherdukpens 
who live very close to each other (the distance between two different tribal habitats cannot even go beyond ten kilometres away from each other). However, their culture is seen starkly different. The people are divided into two cultural groups based on their socio-religious affinities. While the Monpas and Sherdukpens follow the lamaistic tradition of Mahayana Buddhism, practice terrace farming and pastoralism; the Akas, Mijis and Buguns worship the Sun and Moon God as their original ancestors and practice jhumming or shifting cultivation invoking deities from nature and making animal sacrifices (NIC, West Kameng, 28.9.2020). While the traditional Monpa male attire includes a maroon or black shuba or todung (cloak), aliphudung (jacket), dornath or dorna (trousers) and khutung/gamu/chitpajambo (cap made of yak hair), that of a woman consists of a maroon, red or whitetodung, a red or maroonsinka (gown) and a waist belt called mukhok or chhudang (Singh, 1995, p. 216).

To go more specific, even the Monpas of West Kameng have their own classifications that is, the But Monpas, Chug Monpas, Dirang Monpas, Kalaktang Monpas and Lish Monpas. These groups differ from each other in their dialects and many other cultural traits - their inclination towards religious issues, their orientation towards attires, postures and dances. To exemplify, section-wise Ajilamu dance differs from each other in dress, costumes, folk songs, rhythm, use of cymbals, and body movements and expression. However, all they go to suggest a homogenised identity. Such cultural and traditional heterogeneity offers an exotic rendition to the district's homogeneity/solidarity.

While the attire of a Sherdukpen male living geographically proximate to the Monpas, includes asapay or endi-chadar(shawl), akoyokor lidik (a full-sleeve jacket), a mukhok (waist belt) and a dao (machete in a scabbard), a woman wears the sinka (white cotton or silk gown)(Singh, 1995, p. 288). Similar is the kind of variations found with the dressing codes of the Buguns and the cognate tribes- Akas and Mijis.
One of the Aka attire, a head-dress Ghaga, a silver cap is not prepared by them but collected from either the plains or the northern tribes like Sherdukpen and Monpa(Nimachow, 2013, p. 208).This is one area where the Akas, Sherdukpens and Monpas are found permeable so far practicing culture is concerned. The Buguns do have relations with their neighbouring tribes, Monpas, Sherdukpens, Akas and Mijis despite having different cultural practices. In olden days both Buguns and Sherdukpens made alliances to defend them from the attack of other tribes. Even they had made alliances based on their clan(Pandey, 1996, p. 36).

Information for tribes of Arunachal Pradesh migrating to present habitats with stays at places and professing almost similar kind of language and culture and continuing it long is highlighted by J. Nath (Nath, 2013, pp. 72-79). He goes to write that tribes on the north bank of Brahmaputra migrated from Tibet from 6th to 8th Century (Nath, 2000, p. 16), stayed there for centuries which allowed them to come closer to each other. This led to the beginning of a common religion and culture. The tribes since their arrival to present Arunachal Pradesh did not become as engaging as the Sherdukpens from the 7th- 8th Century till date (Gazetteers of India, 1996, p. 31) and the Monpas from 17th Century till date. The Sherdukpens came into contact with the Assamese society from the 7th8th Century through some family relation of Japtang, the common forefather of all the Sherdukpens except for the Chaos (lower origin compared to Thongs of the higher); and the Monpas established their administrative and trade relation with Lhasa (Nath, 2013, p. 73). This could be one of the reasons for both Sherdukpens and Monpas being similar in many of their cultural practices.

Almost all the major tribes believe in animism and shamanism. This is a common ground where their culture is allowed to grow to mutually translate one other's customs or traditions into one's own. Both Monpas and Sherdukpens profess Buddhism. Their villages reflect an aura of religious activities, and their festivals do 
portray homogeneity. Both observe with propitiousness the Tibetan Calendar dates 8th, 10th, 15th, 25th and 30th, important for the Buddhist laity. When free, they engage themselves in religious activities almost involuntarily; fixing prayer flag poles-big and small on the entrance of a home or at very distinct and open places especially atop the hill, visiting Gompas, burning butter in buttercups before the Lord Buddha, muttering Om Mane Padme Humor even counting rosary (a wreath of beads) constantly for the attainment of Nirvana extricating oneself from the chain of indescribable sufferings. Exchanging gifts is also institutionalised among themselves. Such religious beliefs and atonement commonly believed and practiced to carry them along with a homogeneous culture even if heterogeneity classifies them different.

The world is becoming one cultural unit, and there is a reification of fluid social practices by cultural monads which in fact creates the notion of 'insiders' and 'outsiders' and sets up a rigid structure of 'inclusion' and 'exclusion'. This is quite contextual to Buddhism practiced among Monpas and Sherdukpens and how Tibetans as an exterior cultural monad become a part of their culture. In such kind of situation, the hermeneutics of difference is replaced by an attitude of practice, which not only tries to understand each other but tries too to move on to ways of arriving at sets of communicative practices for an acceptable common solution to the problems of the society. It too is quite appropriate in the context of West Kamengwhich encourages multidimensional cultures to be practised and followed.

Even the Miji-origin-myth from Tibet is quite akin to both Monpa and Sherdukpen belief (Nath, 2012, p. 92). Their forcible conversion to Buddhism probably by the Monpas and their nature of dreams about the Monpas, Buguns and Nyishis suggest a more profound crosscultural link between them and the Monpas (Nath, 2012, p. 92). The Monpa dream of fall of tooth indicating the death of a family member or close relative is same as that of the Mijis; their dream of river crossing indicates the death of himself, in reality, is related to the death of a close relative in case of the Mijis; and the dream of someone taking a bath symbolises the real loss of some property is too same in nature with dreams of the Mijis (Nath, 2005, pp. 137$138 / 2012$, pp. 92-93). They used to believe that dreams are the immediate index of misfortunes and diseases and the prescriptions thereof are for immediate remedy. At the bottom of all such cause and effect are the evil spirits, the agents of punishment for one's deeds in this life or many past lives of a man. This goes to suffice a closer homogeneity within heterogeneity between these tribes.

Striking similarities in several aspects of cultural pursuits are also observed among the Akas and Mijis. Language is one of the essential elements of a society's culture. Similarities and dissimilarities among languages are studied to understand the diffusion and interaction of people around the world. It is a significant characteristic of a region and a source of pride for the people and a symbol of cultural unity. Languages or dialects spoken over an area or region speak of the cultures adopted and practiced. It provides uniqueness to culture. Although the Akas and Mijis have cultural and social ties, the respective dialects show stark differences. The intonation in Miji does not have the same striking variations as Aka has. Miji, in some respects, seems to provide a link, albeit a tenuous one, between Aka and the neighbouring group to the East, that is, the Central group (the Nyishi). On numerals, an interesting note is observed. Numbers up to five in Miji are similar to those of the Central group whereas those from six to nine are close to Aka (six- gyre - reh; seven- mro-mya; eight- sigzisigin; nine- sthi-sithin and ten-ghi-lin in case of Aka and Miji respectively). In Aka and Miji, again, numbers like thirty and forty are stated in terms of 'ten-three' (zi-ghi, githin-lin) or 'ten-four' (piyi-ghi, bli-lin) unlike in the languages of the Central group (Nimachow, 2013, pp. 217-218).

The Mijis are said to have come in contact with the Assamese society through the Akas who were in contact with the Assamese people and might have been moved by some finer elements 
of social life. They could have been influenced by the Monpas also who, under the influence of Tibetan Buddhism have developed finer aesthetics in the social sphere (Nath, 2012, p. 14).The term, Miji is a name given to them by the Akas. The Tibeto-Burman term emi or eme means fire and $j i$ means to give. Thus, Miji means 'giver of fire'. And it speaks history. Despite being cognate and having close relations (both are believed to have migrated to their present habitats in the 6th/7th Century), the Mijis remained in the hills whereas the Akas settled down in the Assam plains. When the Akas moved to the hills, they might not have carried any means for making fire, which led them to ask for fire from the neighbour, the Mijis (Singh, 1995, pp. 24-30). Hence such name is attributed.

Going by the origin and migration beliefs, it is believed that the Mijis migrated from Tibet together with the Akas, who are identical in language and culture with the provision of intermarriage between them. They practise tribe endogamy and clan exogamy, and the endogamy between these two tribes suggests that they constituted as one ethnic entity in the past, till the Sajolang emerged as another chief tribe in that tribal milieu (Nath, 2012, p. 27). The Aka festival Netriidow is observed almost in the same way as the Chindang of the Mijis. Food habits and taboos are too strikingly similar to each other. Both tribes practised tattooing until the other day, but now not seen among youngsters. The Miji traditional village council is called nimiyang or mele or raiz; the last two terms are borrowed from the Akas (Nath, 2012, p. 132). Even the Miji priest Givi could perform rituals for the Akas (Singh, 1995, p. 203). All of these entail a homogeneous culture proliferating among these tribes despite heterogeneity observed.

It is quite common that society generally includes many groups/communities with their own distinct customs and ways of life, which goes to certify that each group has its own culture and anyone or some of them may dominate over others. The other cultures stand different from and get disapproved by the dominant culture of society. The dominant group, being possessive of a single way of understanding and organising the different areas of life, may not allow itself to accept a common agenda and belief system. The people in dominated cultures naturally unite to resist the dominant culture's policies and practices. These resistance movements, as Bhikhu Parekh puts, are formed to struggle for recognition of identity and differences or of identity-related differences (Parekh, 2009, pp. 267-284).

The material transition of the tribes is being reflected in the cultural attitude of band society which has got its own value system - the value system of a cog theory by which every member of the group is considered an essential member and it is the responsibility of all other members to offer individual member all possible protection. The Social Cognitive Theory by Albert Bandura, quite interestingly fits in here in case of the tribes psychologically going homogeneous within heterogeneity which ascribes acquisition of individual's knowledge directly to observing others within the context of social interactions and experiences. The theory goes to say that when people observe a model performing behaviour, they remember the sequence of events and use this information to guide subsequent behaviours. Observing a model can also prompt the viewer to get engaged in behaviour they already learned (Bandura, 2008, pp. 94-124). In other words, people do not learn new behaviours solely by trying them or either succeeding or failing, but rather, the survival of humanity is dependent upon the replication of the actions of others.

Going by the theory on roots of culture and pluriculturalism, a contrast image in cultural format comes to the surface taking 'roots' as part of a discourse on authenticity. This leads to a dichotomy-the Self and Other, between which relations tend to grow hermeneutically. Probably, monolingual and monocultural societies leave no other choice with them. However, the world rather spreads out in interconnecting plurilingual and pluricultural structures. As if it goes closer to Deleuze and Guattari's image of the rhizome, which is characterised by heterogeneity and by its 
potentiality to create free (arbitrary) relationships among the diverse areas. Trees and roots manoeuvre towards one point whereas the rhizome with a contrast multiplies diversifies and configures various roots so that the primacy of an original root becomes indistinct in the web of relationship (Deleuze et al., 1990, p. 15). Such a situation emerges out of sensitivity to pluricultural conditions.

\section{Conclusion}

This study was an attempt to demonstrate cultural homogeneity within heterogeneity amongst the tribes -Akas, Buguns, Mijis, Monpas, Sajalongs and Sherdukpens of West Kameng of Arunachal Pradesh. To conclude, as against the linearity of roots, the rhizome perforce produces heterogeneous relationships; this holds an exciting implication for cultural diversity. The linguistic and cultural heterogeneity and complexity of Arunachal Pradesh in general and West Kameng, in particular, remain as part of a flexible cultural, social and religious practice resisting the homogenisation of the classificatory order. However, there is some under-current mechanically flowing closer intrinsically to each other for a more generous space of homogeneity. It strongly emphasises to sensitivity to similarity instead of varied committing dissimilarities. This is, of course, a conscientious move against a system and a culture which negotiate between homogenised units of a stable 'Self' and an equally stable 'Other'. This is probably the area, as stated above, where the author finds a little space to compare between homogeneity vs heterogeneity and relates an area specific to district West Kameng displaying as a palette of cultural diversity.

\section{References}

Abid, Mohammad (2004). Political modernisation : The concept, contours and dynamics. The Indian Journal of Political Science, 65 (4) (Oct.-Dec.), pp. 590-602. Bandura, A. (1986). Social foundations of thought and action: A social cognitive theory. Englewood Cliffs, N.J.: Prentice-Hall.
Bandura, A. (2008). Social cognitive theory of mass communication. In J. Bryant \& M. B. Oliver (Eds.), Media Effects: Advances in Theory and Research. Routledge.

Barthakur, Raju (2006). Winds of change: Arunachalee in tradition and transition. Indian Folklife, Serial No.22, July.

Behaviorial Change Theories (2020,22 October). The Social Cognitive Theory. https://sphweb.bumc.bu.edu/otlt/MPHModules/SB/BehavioralChangeTheories/Behavi oralChangeTheories5.html\#headingtaglink_1

Bhatti, Anil (2009). Culture, diversity and similarity: A reflection on heterogeneity and homogeneity. Social Scientist, 37(7-8), JulyAugust, New Delhi.

Bloch, Ernst (1977). Nonsynchronism and the obligation to its dialectics. (first published in German 1932), Trans. Mark Ritter, New German Critique. Duke University Press, No. 11.

Bose, M. L. (1997). History of Arunachal Pradesh. Concept Publishing Company.

Cambridge English Dictionary (2020). https://dictionary.cambridge.org/dictionary/en glish/culture

Carl Schmitt, Verfassungslehre, Berlin, 1928.

Chaudhuri, Sarit K. and Chaudhuri, Sucheta S. (2016). Beads of Arunachal Pradesh: Emerging Cultural Context, Niyogi Books.

Cole, Nicki Lisa (2019). Understanding Acculturation and Why It Happens. ThoughtCo. https://www.thoughtco.com/acculturationdefinition-3026039

Deleuze, Gilles, Guattari, Felix, \& Plateaux, Mille, (1990), Paris. (Engl. A Thousand Plateaus, Capitalism and Schizophrenia, Translated by Brian Masumi, 1988).

Enz, C. A. (1986). New directions for crosscultural studies: Linking organizational and societal cultures. In R. N. Farmer (Ed.), Advances in International Comparative Management: A Research Annual, Vol. 2, JAI Press. 
Gardner, Vinita Kaul (2019), The thrilling tales of the tribals of Arunachal Pradesh. Sangya Chaudhury (Ed.). Tribal Culture of India, New Delhi:The Indian Trust for Rural Heritage and Development (ITRHD).

Gazetteers of India (1996) - Arunachal Pradesh, East Kameng, West Kameng and Tawang Districts, Shillong.

Grewal, D. S. (1997). Tribes of Arunachal Pradesh: Identity, Culture and Languages, Delhi: South Asia Publications.

Grugel, Jean, Riggirozzi, Pia, \& Thirkell-White, Ben (2008). Beyond the Washington consensus? Asia and Latin America in search of more autonomous development. International Affairs, 84(3), 502-503.

Gy, Pierre M. Ed. (1992). Logical analysis of the concepts of homogeneity and heterogeneity. Data Handling in Science and Technology, Volume 10, Elsevier. https://www.sciencedirect.com/science/article /pii/S0922348708700765

Hendricks, Beth. Marshall McLuhan \& the Global Village Concept. study.com. https://study.com/academy/lesson/marshallmcluhan-the-global-village-concept.html

Joshi, H. G. (2005). Arunachal Pradesh: Past and Present. Mittal Publications.

Mibang, Tamo and Behera, M. C. (Ed.) (2007). Tribal Studies: Emerging Frontiers of Knowledge. Mittal Publications.

Nadimpally, Lasya (2017). Arunachal Pradesh: tribes \& traditions. Outlook Traveller. https://www.outlookindia.com/traveller/otgetaway-guides/arunachal-pradesh-tribestraditions/

Nath, Jogendra (2000). Cultural Heritage of the Tribal Societies, Vol. I: The Adis, Omsons Publications.

Nath, Jogendra (2005). The Cultural Heritage of Tribal Societies, Vol. II: The Monpas, Omsons Publications.

Nath, Jogendra (2012).The Cultural History of the Mijis of Arunachal Pradesh. Prithibi

Prakashan.
Nath, Jogendra (2013).Economic growth of Arunachal tribes in relation to their cultures through the ages. In H. Lasa, S. C. Nayak \& N. Thupten (Eds.), Tribal Area Development and Northeast India. Adhyayan Publishers.

Nath, Jogendra (2014). Cultural History of the Sherdukpens of Arunachal Pradesh. Ajir Pratinidhi Publication.

National Informatics Centre (2020). Culture and heritage. West Kameng District.

Government of Arunachal Pradesh, Ministry of Electronics and Information Technology, Government of India.

https://westkameng.nic.in/culture-

heritage/\#: :text=The\%20entire\%20population \%20of\%20the,other\%2C\%20living\%20there\%20 separate\%20lives.

Nimachow, Gibji (2013). The Akas: Land and People. Commonwealth Publishers.

O'Byrne, Darren J. and Hensby, Alexander (2011). Globalization: The global village. Theorizing Global Studies, January, DOI: 10.1007/978-0-230-34506-5_2

Pandey, B. B. (1996). The Buguns: A Tribe in Transition. Himalayan Publishers.

Parekh, Bhikhu (2009). Logic of identity.

Politics, Philosophy \& Economics, 8(3), 267-284.

Pathak, Guptajit and Gogoi, Raju (2008).

Cultural Fiesta in the Island of Peace: Arunachal Pradesh, Mittal Publications.

Singh, K. S. (Ed.) (1995). People of IndiaArunachal Pradesh, Vol. XIV. Seagull Books.

Singh, Sudhir Kumar \& Riddi, Ashan (2017). PreColonial History and Traditions of Arunachal Pradesh, DVS Publishers.

Subrahmanyam, Sanjay (1997). Connected histories: Notes towards a reconfiguration of early modern Eurasia. Modern Asian Studies, 31(3), 735-762.

Tylor, Edward (1871). Primitive culture. Vol 1. J.P. Putnam's Son. 


\section{Acknowledgements}

I deeply acknowledge the anonymous reviewers of my article for so minutely reviewing my article inputs for revision of the same.

\section{About the Author}

Dr Nayak obtained his MA, M.Phil and Ph.D from Utkal University, Bhubaneswar, Odisha. His research interests include History of Modern India, History and Culture of Arunachal Pradesh. His publications include Reinventing Maritime Entrepreneurial and Infrastructural Heritage up to 19th Century Odisha, Ganeswar Nayak (Ed.). Mapping Economic History of Colonial Odisha,
Kunal Publishers, 2018; India's Northeast and Southeast Asia: Understanding Trade through Arunachal Pradesh, Proceedings of International Conference on Indian Trade and Commerce: Past, Present \& Future (ICITC), Institute of Media Studies, Bhubaneswar, Odisha, 2018; Environmental History and Human Culture: Arunachal Pradesh Experience, Proceedings of 40th Session of North East India History Association (PNEIHA), Karmashree Hiteswar Saikia College, Guwahati on 24-26 October 2019 (forthcoming). Besides, his articles were also published in the Proceedings of Indian History Congress in 2007; Economic and Political Weekly in 2011 and Third Concept in 2017. 